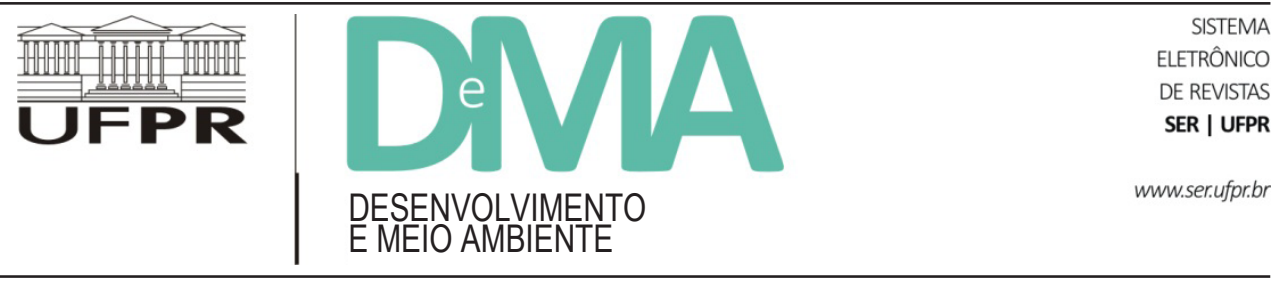

\title{
Turning Subsistence Peasants into Ecosystem Servants: Inequality and the Production of Natural Resources in Lao P.D.R.
}

\section{Transformando camponeses de subsistência em servos de ecossistemas: desigualdade e a produção de recursos naturais na República Democrática Popular do Laos}

\author{
Michael KLEINOD ${ }^{1 *}$ \\ ${ }^{1}$ Rheinische Friedrich-Wilhelms, Universität Bonn, Alemanha. \\ *E-mail of contact: mkleinod@uni-bonn.de
}

Article received in November 24, 2015, final version accepted in May 19, 2016.

ABSTRACT: This paper examines the nexus of nature conservation, productivity and domination in inclusive conservation approaches. It argues that the turning of subsistence peasants into "stewards and custodians of biodiversity" (CBD) represents a soft form of domination according to the false alternatives of ecological instrumentality in that local development is subordinated to supposed "natural" constraints. The argument draws from critical theories of societal nature relations (Horkheimer \& Adorno, 2002; Görg, 2003; Moore, 2015) as well as from extensive research on ecotourism as an instrument to reconcile conservation and development in the Lao People's Democratic Republic. From this angle, conservation is seen as a way to produce "natural" resources building on, perpetuating and creating various social inequities, based on the fiction that "nature" is essentially non-human. This case is made with regard to National Protected Areas in Laos, which are designed explicitly to accommodate local people's needs. Among other things, ecotourism is employed to create a source of income alternative to practices seen as "unsustainable". Thereby, economic and also moral stakes in untouched resources are to be implanted. In such way, a compromise between (rather than a reconciliation of) conservation and development is imposed which is largely alien to the lived realities of local people, and only accounting partly for their needs and aspirations - an imposition which tends to produce its own countercurrents, again tying into productivity and inequality. This paper thus analyzes the workings of the nature/society dualism underlying ecological instrumentality as experienced in ecotourism as a tool for nature conservation in Laos.

Keywords: instrumentality; conservation; ecotourism; Laos.

RESUMO: Este artigo examina o nexo entre conservação da natureza, produtividade e dominação nas abordagens de conservação inclusivas. Argumenta que a transformação de camponeses de subsistência em "administradores e custodiantes de biodiversidade" (CBD) representa uma forma suave de dominação de acordo com as falsas 
alternativas de instrumentalidade ecológica em que o desenvolvimento local é subordinado a supostas limitações "naturais". O argumento se baseia em teorias críticas das relações entre natureza e sociedade (Horkheimer \& Adorno, 2002; Görg, 2003; Moore, 2015), bem como em uma extensa pesquisa sobre o ecoturismo como um instrumento para conciliar conservação e desenvolvimento na República Democrática Popular do Laos. Sob esse ângulo, a conservação é vista como uma forma de produzir recursos "naturais", perpetuando e criando várias desigualdades sociais, com base na ficção de que a "natureza" é essencialmente não humana. Este caso é defendido no que diz respeito às Áreas Nacionais Protegidas no Laos, que são projetadas explicitamente para acomodar as necessidades da população local. Entre outras coisas, o ecoturismo é empregado para criar uma fonte alternativa de renda a práticas vistas como "insustentáveis". Assim, espera-se implantar interesses econômicos e também morais sobre recursos intocados. Desta forma, um compromisso (em vez de uma reconciliação) entre conservação e desenvolvimento é imposto, em grande parte alheio às realidades vividas pela população local, e só respondendo parcialmente às suas necessidades e aspirações - uma imposição que tende a produzir suas próprias contracorrentes, mais uma vez atando produtividade e desigualdade. Este artigo analisa, assim, o funcionamento do dualismo natureza/sociedade, enfatizando a instrumentalidade ecológica experimentada no ecoturismo como ferramenta para a conservação da natureza no Laos.

Palavras-chave: instrumentalidade; conservação; ecoturismo; Laos.

\section{Introduction}

According to the UN, "[s]ince 1990, the world's protected areas have increased in number by $58 \%$ and in their extent by $48 \%$ ", which makes them "now one of the most important land-use allocations on the planet" (Bertzky et al., 2012, p. 6f). Are these good or bad news? Many would intuitively say that nature conservation is good. However, forms of openly exclusionary conservation have aroused much attention with the number of conservation refugees going into the millions (Dowie, 2005). Although such "fortress conservation" is currently experiencing a revival (Adams \& Hutton, 2007), more inclusive forms were designed and implemented worldwide as a consequence of such critique in order to render nature conservation more socially accountable. Instead of simply displacing rural communities, these would participate actively in conservation efforts and at least partly earn their income this way. Ecotourism is, among other strategies, a prime tool to not just finance protected area management, but also turn local people into "stewards and custodians of biodiversity"'. Given the global increase in protected areas in the context of "sustainable development" becoming hegemonic, and with ecotourism as one central source of financing conservation work, the regulatory rationale of turning subsistence peasants into ecosystem servants gains traction.

I argue that not only exclusionary conservation but also inclusive forms, in contrast to their claims of local participation and empowerment, imply social domination and inequality. The focus of this paper is not to simply point out that ecotourism exerts domination, but to specify the form domination takes in ecotourism. Clearly, this paper does not accuse ecotourism of putting supposedly "free" people(s) into dominative relations: subsistence systems are known to be preoccupied with guaranteeing a minimal income in direct dependence on the "caprice of nature", people being "up to the neck in water" (Scott, 1976, p. 22); and they imply social inequality (such as between patrons and

\footnotetext{
1 According to the Convention on Biological Diversity cross section „Tourism and Biodiversity“; http://www.cbd.int/tourism/process.shtml, accessed March 2015.
} 
clients). ${ }^{2}$ Turning subsistence peasants into ecosystem servants thus defines the specific form domination takes in ecotourism as inclusive conservation: as environmental caretakers, peasants are, contrary to their ambition as well as to principal societal possibilities, kept close to the "subsistence crisis zone" in order to safeguard nature's untouchedness. No matter in which guise, nature conservation is principally based on the nature/society dualism which can be considered the root of domination and inequality. In inclusive conservation, domination is not as explicit and open, however, but rather "soft" and clandestine. Furthermore, "conservation" is, contrary to its self-description, productively related to resource extraction in various ways involving social inequality. This argument is based theoretically on critical theories of capitalist nature relations (e.g. Görg, 2003; Moore, 2015). Empirically, it draws from four years of research for a dissertation project on ecotourism in the Lao People's Democratic Republic (Lao P.D.R., or Laos). More specifically, it is informed by interviews with ecotourism advisers, guides and villagers inside of or adjacent to National Protected Areas (NPAs) where ecotourism projects were in operation or envisaged. The argument is not only relevant to Laos, however, which is taken as an example of how inclusive conservation is based on, evolves through, and effects domination and inequality. The main focus is thus the nexus between conservation, productivity and domination/inequality ${ }^{3}$.
I will first demonstrate how conservation is to be understood as a step in the historical production of natural resources and how it is principally related to social domination. In section 2, I turn to nature conservation in Laos, introducing the NPA system and arguing that it is based on the assumption that nature is purest where human disturbance is lowest. In a third step, I turn to ecotourism as a mode of "conservation" and show the ways in which it entails "participatory exclusion" as well as diverse empirical inequalities. My point, again, is not that ecotourism is exclusionary but how this exclusion works under the pretext of local participation. The last step goes on to highlight ways in which "untouched" resources are immediately relevant for (unequal) extraction by situating NPAs within an extractive landscape. The paper concludes on the note that both versions of conservation are problematic since they are based on and effect inequality and domination.

\section{Conservation, resource production and domination}

Westerners tend to think of nature reserves (or even well-tended forests) as residues of some original state of "nature", understood as the realm of the non-human. As such a space, "nature" promises healing for those who suffer from the demands of "modernity", conservationists and academics included. As Marx already notes, however:

\footnotetext{
2 A defining feature of a subsistence economy according to Scott is that the family constitutes a unit of production and of consumption (Scott, 1976, p. 13); in a capitalist society, in contrast, the family is not anymore the unit of production. "Subsistence" does, further, not exclude participation in market economies: various side-businesses are part of the portfolio of subsistence struggle. With the majority of its population engaged in subsistence agriculture, it is still the case in Laos that many "peasants are reluctant to strike out for profits when to do so means upsetting the subsistence routines" (Scott, 1976, p. 22). This is slowly changing, however, and ecotourism plays its part in this transformation.

3 The concepts of domination and inequality are based on different planes of analysis: domination refers to social relations between individuals and institutions; inequality refers to the distribution of properties and assets, such as "capital" (in the sense of Bourdieu) or chances of access to socially desirable resources (see Demirovic, 2014). Perhaps oversimplifying, inequality may be seen as the empirical, surface appearance of deep-seated structures of domination.
} 
Animals and plants which we are accustomed to consider as products of nature, may be, in their present form, not only products of, say, last year's labour, but the result of a gradual transformation continued through many generations under human control, and through the agency of human labour (Marx, 1982, p. 287f).

In principle, thus, nothing supposedly "natural" is unmediated by human action; the biodiversity conserved as "nature" in protected areas would not exist without many generations of labor subjecting the laws of nature to those of a certain societal formation; what is "conserved" is historically produced "nature". The appearance of this historical product as untouched is arguably an effect of the relational logic of the historical labor process itself. As Marx further notes,

The same use-value is both the product of a previous process, and a means of production in a later process. Products are therefore not only results of labour, but also its essential conditions (ibid).

Use-values, results of human appropriation of the material environment, appear as either mediated products or as immediate means of production relative to a particular phase of the overall production process; or more generally: "Nature, as the material with which men are faced, can only be regarded as unformed material from the point of view of the purposes of human activity" (Schmidt, 1971, p. 63). Nature is an immediately given resource only from a specific practical position; in general, which things represent resources and how they are appropriated is always already mediated through historical practice. From the conservation perspective, "nature" (pristine environment), a product of human mediation, is immediately given and appears as first nature. The establishment of a nature reserve at once disregards and appropriates the labor humans have invested in creating the diversity that is now to be "protected", e.g. from past producers. The enclosure of zones of non-extraction is a top-down process, designated and established by decree, in cooperation of national governments and the international community. Local people usually do not have much say in these decisions, let alone in Laos. Through such disregard the establishment of an NPA is an act of violence, based on a legalized view of nature as wilderness.

The idea of "nature" as non-human is thus a function of the relationality of historical practice. The idealization of "untouched nature" from which nature reserves derive their legitimation among the global middle classes is an ideological mirror image of capitalist resource exploitation: if "nature ceased to serve merely as raw material, it would no longer need idolization" (Schmidt, 1971, p. 154). Both, resource depletion and nature idolization reinforce each other on the common base that nature is a mere resource to be turned socially productive. The nature/society dualism implied in the fantasy of nonhuman, untouched "nature" as much as in ruthless resource depletion was seen by the "old Frankfurt School" as the root of domination of people over nature, i.e. over the environment, other people as well as over oneself. This duality is at the core of instrumental reason (see Horkheimer \& Adorno 2002, p. 1-34): not unlike Foucault's notion of governmentality, what I term instrumentality employs an object to fulfill a subject's purpose; the disregard for the inherent purpose of what is appropriated as "object" - the denial of the autonomy of an other (Görg, 2003, p. 41) - is bound to undermine and "haunt" the instrumental relation. Instrumentality is thus inherently crisis-ridden. In its rationale to turn subsistence peasants into ecosystem servants, 
inclusive conservation provides a good example for the practical workings of such instrumental reason. ${ }^{4}$

According to Adorno and others, the nature/ society dualism confronts social practice with false alternatives: a choice between society either dominating nature or society being dominated by it; the inescapability of this choice is not natural but it "is that of power" (Horkheimer/Adorno, 2002, p. 25; Görg, 2003, p. 19ff). Either social development dominates and subjects nature to its purposes, or it subjects development to supposed natural constraints; in both cases, domination is effected. The conversion of peasants into ecosystem servants belongs to the second alternative. This argument is based on the somewhat utopian idea that while human history thus far was always characterized by the contradictions of nature domination, different ways of relating to nature are principally possible (Görg, 2003, p. 38).

Since the historical experience of an ecological crisis and the rise of the environmental movement in the 1970s, protected areas have become "factories" of raw materials, first of all of genetic diversity $^{5}$ (see Görg, 2003, p. 270ff; Kelly, 2011, p. 636f). In the current phase of capitalist development, environmental preservation is a condition of sustained growth: the preservation of the material, mainly genetic, preconditions of future private appropriation (Görg, 2003, p. 153). A nature reserve thus not only represents an act of appropriating past human labor by enclosing a realm of untouched nature. As such it is, furthermore, itself a unit of production, given the labor and finance invested in keeping up the boundary between nature and (local) society: the population may have to be resettled out of the confines of the protected area (PA); regulations have to be enforced, boundaries demarcated, awareness about legal matters raised, biological research conducted. From the viewpoint of "total economic value" approaches, furthermore, NPAs are regarded as "productive units" rather than as locked-up resources: the "environmental services" an intact NPA delivers to social production, ranging from the most immediate to the most general and global level, are measured in monetary terms to be integrated in the overall account balance (e.g. ICEM, 2003). This is how ecological capitalism valorizes nature.

PAs are thus products of past human-environment interaction as well as productive entities themselves. The rupture they impose on the socioecological history of a locality signals a new phase in the production of natural resources characterized by legal appropriation of past labor, effectively separating people from land (Kelly, 2011). With the establishment of PAs in Laos, the nature/society dualism becomes implanted in a context where it has not existed before (section 3). It becomes a social fact establishing a treasury of valuable "natural" resources ${ }^{6}$ while restricting the

\footnotetext{
4 This is not to claim that subsistence peasants are somewhat beyond an instrumental take on the environment, animals, themselves, or their fellows. In fact, Horkheimer and Adorno are clear that also magic and ritual sacrifice, arguably cultural traits of subsistence societies, are instrumental, employed for self-preservation. With regard to ecotourism, Butcher (2007, p. 124) makes clear that there "is no environmentalism of the poor".

5 According to the German Gesellschaft für Chemische Technik und Biotechnologie e.V. since decades more than $50 \%$ of newly registered pharmaceuticals were low-molecular "natural" substances or derived from such: http://www.dechema.de/13_2007-p-122682.htm, accessed March 2015.

6 To say that past labor (i.e. human-environment interaction) produced the biodiversity that is now to be protected does not mean that labor was applied intentionally in order to produce the biological diversity or create a gene pool in-situ. Nonetheless, the historical shaping of the environment, e.g. by "slash-and-burn" in shifting agriculture arrangements, results in certain kinds of habitats and directly influences the amount and
} 
sustenance of local people to certain, "sustainable", forms of income. This constellation - natural riches next to continued poverty - makes the violation of PA regulations rather likely, especially when weakly enforced (section 5).

\section{Laos and its National Protected Areas}

The Lao P.D.R. is a so-called "least developed country" (LDC) surrounded by China, Thailand, Cambodia and Vietnam. The Lao government's ambition is to leave LDC status by 2020. This is largely achieved via the "turning of land into capital" by granting foreign investors (mainly China, Vietnam, Thailand) and domestic business access to its natural resources for mining, plantation agriculture or hydroelectricity generation. While Laos, like Southeast Asia as a whole, has served as resource provider for hundreds of years, the idea of nature conservation is a relatively late arriver at this resource frontier. The necessity of forest to be conserved is rather new in Laos.

In precolonial times, upland forests presented an obstacle to lowland statecraft (Scott, 2009). The forest ( $p a a)$ and its inhabitants (khaa, "slaves") were seen as antitheses of civilized lowland realms (meuang) ruled by a Buddhist god-king; forest and polity stood in a dialectical relation (Singh, 2012, p. 43; Turton, 2000). For the precolonial political ecology, that is, forest represented a threat and its civilization an act of virtue and potency. Daily life outside the court and monasteries consisted in dealing with the "caprice of nature" (Scott, 1976, p. 9). When French explorers visited their soonto-be protectorate, they ushered in a new phase in the production of Laos' landscape. Francis Garnier recalls the historical Mekong expedition of the late-1860s: "Indeed, our whole story could be said to take place in a single unending forest" (Garnier and Tips in Phimmavong et al., 2009, p. 505). What the French had before their capitalist eyes was a full-fledged political economy based on simple production (Marx, Bourdieu), that is, the production and trade of use-values in order to be consumed, together with a comparably low level of technological development ${ }^{7}$, so that the forest they observed was seen as unprofitably used land. The opening up and capitalist valorization of Laos was central to French colonial endeavors (Gunn, 2003; Stuart-Fox, 2002). Continuous depopulation and underdevelopment during the American war and post-independence left the forests of Laos relatively abundant and comparably untouched by large-scale capitalist development until recently.

Whereas Laos' big revolutionary brother Vietnam saw its first national park established in 1962 by Ho Chi Minh himself (McElwee, 2002, p. 29), national-level protected areas arrived in the Lao uplands only after its turn to the market economy in the mid-1980s, when the first biogeographic analyses of potential sites for conservation were carried out (MacKinnon \& MacKinnon, 1986). Subsequent surveys led to the First National Forestry Conference in 1989, which culminated in the Tropical Forestry and Action Plan of 1990, making it the government's goal to bring $10.5 \%$ of the total

composition of biodiversity as well as soil condition, local climate, water quality etc. Clearly, certain natural features are mediated by human labor to a higher degree than are others.

7 The aim of capitalist production, in contrast, is the realization of exchange value to accumulate surplus arising from human labor. Systemically, use-values in capitalism are not produced for consumption, primarily, but in order to be sold. This surplus-driven logic knows no inherent limit like simple production does. 
land area under protection (Robichaud et al., 2001). One principle of the planned national protected area system was to represent the full range of the country's ecosystems. From initially 68 proposed sites, 29 were considered suitable, but they were further reduced to 17 . These sites, plus one added for its historical significance, were officially announced as National Biodiversity Conservation Areas (NBCAs, later termed NPAs) in 1993 (along with several provincial and district protected areas). Today, there are 24 NPAs and two biodiversity corridors, accounting for about $15 \%$ of total land area. Provincial and district conservation areas add around $5 \%{ }^{8}$.

Lao PDR disposes of one of the most upto-date and progressive protected area systems worldwide in terms of its ecological-scientific base as well as the conservation approaches endorsed by the government. Lao NPAs are decidedly inclusive, involving the participation of local populations (ICEM, 2003, p. 25) and explicitly calling for "integrated conservation and development projects" (ICDPs), such as ecotourism (section 4). NPAs fall under the legal category of conservation forest ${ }^{9}$. According to the Forest Law (2007, Art. 11), Lao NPAs are legitimately open for interests in tourism and research, that is, pursuits of milieus geographically and socially distant from peasants living within or adjacent to NPAs.

Their inclusiveness must thus be taken with a grain salt. It is sometimes stated that these areas fall into the international IUCN protected area category
IV (Habitat/Species Management Area) and are thus not comparable to national parks elsewhere (for example, in Vietnam). Such categorization seems imprecise, however: despite relatively low levels of exclusion, NPAs are "inclusive fortresses", allowing locals to remain close to or even inside while still being driven by an exclusionary logic of zonation. Within the Total Protection Zone "it is strictly prohibited to conduct any forestry activity, to harvest any forest products, including unauthorized entry". The Controlled Use Zone "must be protected similar to the Total Protection Zone, but people are allowed to use wood and forest products according to the management plan". Moreover, Corridor Zones are "managed areas for preserving tracts of forest to provide passages for animals", while Buffer zones "prevent any encroachment and destruction in the Conservation Forest" (Forest Law 2007, Art 24) $)^{10}$.

Zonation is thus a perfect example of how ideological oppositions such as nature vs. society are rendered practicable by gradation: the total protection zone (or core zone) is the one constructed closest to the ideal of pure non-human nature, with the highest degree of exclusion. Exclusivity is graded down towards local economic reproduction and development by controlled use zones where villagers are allowed to use forest products according to the management plan which relies on national law; regulations are often complicated for locals to understand and thus require continuous awareness trainings. NPA establishment, furthermore, ties into

\footnotetext{
8 See: https://www.giz.de/en/worldwide/17453.html, accessed on September 2014.

9 Conservation forests are distinguished from protection forests, which are seen as "more or less unmanaged and vaguely defined areas in steep terrain along international borders" (ICEM, 2003, p. 45). Protection Forests cover 8.2 million ha.

10 The difference between buffer zones and controlled use zones indicates further gradation with a lower grade of prohibition on the part of "conservation" (controlled use zone) and a higher grade of prohibition on the part of "development" (buffer zone). Personally, I have not heard practitioners talk about "buffer zones", and if so, then identifying them with "controlled use zones" (like total protection zone and core zone). Corridor zones are an exception.
} 
land classification and allocation as well as relocation programs which are continually criticized for their adverse social impacts (e.g. Vandergeest, 2003; Baird \& Shoemaker, 2005; Baird, 2011).

However, throughout the reports and papers on environmental protection in Laos, significant gaps between legal discourse and on-the-ground reality are noted. Due to lack of capacity for environmental protection on all levels of government and a prioritization of large-scale development projects, conservation policy is hardly enforced: "only three NPAs in the country have reasonable levels of site management" (GEF, 2012, p. 15). One of these is Nam Et-Phou Loei NPA where Wildlife Conservation Society (WCS) pursues its mandate to protect one of the last resorts of the Indochinese tiger in collaboration with the Lao government and international financiers (such as World Bank and GIZ). Park management consists of several task forces: an enforcement team patrols the NPA and surrounding markets; an outreach unit raises awareness about regulations in village workshops and advertisement; a monitoring and research unit keeps track of project outcomes; a land-use management team aims to increase agricultural production while minimizing forest degradation and human-wildlife conflicts (e.g. with regard to tigers, leopards or wild pigs); and an ecotourism unit seeks to implant economic stakes for local communities in untouched resources.

In protected areas, the idea that "nature" is principally purest where human "disturbance" is lowest becomes a factual constraint. This construct is socially biased, emerging from specific historical experiences and conditions in the industrialized centers of the global social structure - and from certain well-educated middle class experiences within the centers. Reflecting the perceptions of a certain social spectrum of industrialized society, protected areas therefore do not simply limit sociality per se, but favor certain socialities over others. According to the law, the purpose of preservation is the maintenance of biodiversity, history and "culture" as national resources as well as the creation of work and leisure opportunities for the educated (Western) middle-class. The interests of local populations in alleviating subsistence crisis are downplayed as they are kept close to the "caprice of nature" while their resource use is legally restricted. For these populations, conservation often exacerbates their marginality, making it more complicated and difficult to secure livelihoods instead of alleviating poverty ${ }^{11}$. Serious economic constraints are put on subsistence cultures by such "post-industrial" nature relations that are transnationally brokered, nationally adopted and then implemented. Where such "world-making projects" (Igoe, 2010, p. 377) make the fiction of non-human nature real, local practices are subjugated to an environmental management regime, that turns them into objects of socio-ecological engineering. ${ }^{12}$

Nature conservation is somewhat external to Lao lived realities for cultural and economic reasons. Lao livelihoods rely on older "sociocultures" (Rehbein, 2007), such as subsistence ecologies and ethics, to which an abstract notion of "nature"

\footnotetext{
11 Villagers adjacent to Nam Ha NPA openly expressed their discontent with the NPA, eager to "discuss again" and very much in favor of earning their living through commercial rubber production as well as tourism.

12 People of the Lao uplands were clearly marginalized and objects of power politics already in earlier historical phases: "slaves" in precolonial times, they constituted the bulk of corvée laborers under colonialism; in the so-called Vietnam War, upland groups were recruited by warring parties to fight clandestinely for or against the spread of communism in Asia. The quantity of unexploded ordnance especially in the uplands and the establishment of re-education camps after "revolution" shut off the uplands from far-reaching socio-economic development until the mid-1980s.
} 
is foreign (Singh, 2012, p. 45); their current state of underdevelopment perpetuates these notions as continued marginality necessitates relying on "traditional", subsistence-based forms of securing livelihood. Increasingly, peasants seek to meet their subsistence through cultivation of cash crops such as rubber, corn or banana, and the opposition of capital (e.g. ownership in land) and wage labor is being established. From the perspective of people who fight a daily battle against the "caprice of nature" in order to harness it for survival, the non-use of resources immediately at hand does not come natural but is imposed by actors from very different socioeconomic and cultural realms. Because of such imposition, conservation in the form of PAs involves the power of global socio-economic differentials. This becomes clearer when looking at ecotourism as a central tool of inclusive conservation.

\section{Ecotourism in Lao NPAs}

Ecotourism is a contested term and used in a variety of contexts. For the sake of clarity, I follow here the definition of the International Ecotourism Society (TIES) for which ecotourism is "responsible travel to natural areas that conserves the environment, sustains the well-being of the local people, and involves interpretation and education". Leaving the educational part aside, this form of travel seeks to integrate the two antagonists of the nature/society dualism: conservation and development. Rural development is coupled with nature conservation: communities and park management are integrated into one structure distributing tourism income according to rights and responsibilities; tourism pays for park management and contributes to local funds. For the community, ecotourism is ideally income alternative to "income" derived from unsustainable resource extraction. If money is derived from untouched nature, it is hoped, conservation will also attain a moral value for locals so that they will "become stewards and custodians of biodiversity" (above).

Like conservation, ecotourism arrived rather late at the resource frontier of Laos. During French colonialism and the US involvement, tourism to Laos was existent but marginal. The communist period between 1975 and the mid-1980s shut Laos virtually off from the tourist landscape but since the gradual opening up, international tourism has become a major foreign exchange earner. In the early 1990s, much tourism consisted in unregulated travel into the mysterious Golden Triangle, building on the hippie trails of the $60 \mathrm{~s}$ and 70 s. This kind of travel was regarded with suspicion and seen as detrimental by Lao officials and tourism experts alike.

Interrelated concerns - such as, the need to control tourist movements in remote ethnic minority areas; the political aim of countering opium production and slash-and-burn cultivation which were and are perceived as markers of poverty, and to instead use international tourism as a way of poverty alleviation; the ambition to protect important ecosystems - led from 1996 onwards to a model ecotourism project in Nam Ha NPA, situated in the province of Luang Namtha. It has run through two phases of implementation by UNESCOs Bangkok office and related national and international funding. With almost one technical advisor per target village in the first phase, "it is unlikely there is a development project in the world that has maintained this level of expertise relative to the number of target communities" (Lyttleton \& Allcock, 2002, p. 47). The model project in Nam Ha is widely regarded a success. Not only did it prove that tourism in Laos can support local communities: it also pioneered various tools to be employed by 
following projects, such as site selection methods, distribution structures of obligations and revenues, awareness raising and education tools, institutions to coordinate several actors, measures to involve and monitor the private sector, carrying capacity limits to the amount of tourists visiting the villages, etc. The Nam Ha project set precedents also in terms of personnel as a number of its advisors remain influential in sustainable tourism development in Laos. Today, ecotourism has been implemented in about half of the NPAs in Laos. Moreover, the logic of integrating conservation and development through the appreciation of nature and ethnic culture is employed in provincial and district conservation areas as well as beyond areas explicitly designated for conservation or protection of resources.

Ecotourism comes quite naturally with a form of conservation work where nature must "pay its way" (Duffy, 2002, p. 47), such as, through tourism revenue. Although ecotourism proclaims local ownership and participation and may to a certain extent alleviate rural livelihoods struck by poverty, it nevertheless comes with the strings of domination and inequality attached, and necessarily so. Employed for the sake of conservation, ecotourism affirms and transforms the social power inherent in the establishment of a protected area in various ways. Ecotourism is, first of all, a realization of national law that legitimizes touristic access to NPA while illegalizing local extraction, lending legitimacy to supra-local, affluent interest; locals are legal in the core zone only as tourist guides, carriers or helpers of management staff. Just as the population has not much say in NPA designation, ecotourism projects come to them apparently "at will" from outside actors such as international organizations and government agencies; it does not grow out of the livelihoods of local people - which it must, to some degree at least, in order to be sustainable and really address local issues. Locations are picked according to interests other than those of the population that will have to live with what is implemented, and the local community is mostly the last "stakeholders" consulted after provincial and district arrangements have been made.

The foreignness of conservation and ecotourism further translates into exclusion via inclusion: the urge to pay huge sums in order to look at forest and underdeveloped villages is hardly understood by a majority of the Lao people. Due to this cultural and economic unfamiliarity, local hosts remain dependent on external experts teaching them hospitality - despite rich local hosting traditions. Contrary to traditional hospitality, the ecotourism constellation is essentially a service agreement within which the demand of the guest "is king". This demand belongs to actors who are socially and geographically distant from local realities and it is also quite contradictory: the experience of "authentic" places supposedly untouched by modern demands, such as jungle and ethnic lifestyles, can only be realized via all kinds of "inauthentic" developments, from infrastructure to toilets to hygienic food. The visited locality should be developed, but not overly, or visibly. Local unfamiliarity with ecotourism belongs to this demand requiring not touristic professionals but "real" peasants. Relatedly, within the ecotourism optic hosts are never envisioned to become like their guests: they are quasi-natural hosts, legitimate servants of a mainly white Western middle-class searching to escape into nature. This institutional and symbolic setup amounts to participatory exclusion: even though a mindset closer to that of paying visitors would be favorable for success as a service provider, ecotourism precludes hosts from becoming as affluent as their guests. Thereby, their poverty is naturalized, idealized and reproduced; peasant-hosts participate in their social exclusion. 
Given that a protected area is a material force that prefigures social options, it is no contradiction that even local free informed consent in ecotourism implementation is already predetermined by the violence of PA designation and enforcement. Village consent is hardly "free" in reality, however. Advisors are the first to acknowledge the fact that implementation of a project necessarily builds on and perhaps exacerbates existing power inequalities, such as between the sexes, between richer and poorer households, as well as between village elites and regular villagers. Even in open village fora, "you say 'raise your hands' and then people raise their hands because they see their friends, their next door neighbors, raising their hands" (advisor). Often, villagers will not openly oppose to decisions made by the village head and elders while it is the latter who most likely profit from tourism to their village. The problem extents to the establishment of village working groups, such as for hosting, cooking, guiding, handicraft production and sale. As an advisor puts it:

You could say that just by having a differential of benefits within one village creates a problem. Even though we had an open hiring process still a lot of villagers didn't come. Some of them probably didn't come because they did think correctly: I won't be able. Some villagers probably thought: it's not for me, or they didn't feel confident to go to the interview. And I have the suspicion that some villagers told other villagers "nah, you shouldn't go".

Top-down implementation of ecotourism projects often relies on previous internal inequalities: women regularly bear the bulk of the everyday chores in Lao upland village life and are relegated to the reproductive, domestic sphere; in ecotourism, traditional gender roles are maintained in that women rarely become guides or otherwise involved with guests but provide meals, handicraft etc. The wealth gap between households, based mainly on the number of persons as well as amount and quality of land, divides those resourceful enough to try out largely unknown enterprises, such as tourism, and those who are not. The poorest of the poor are unlikely to become active figures in ecotourism work, due to the lack of household members that can be spared from necessary subsistence labor; poverty goes along with a habitualized insecurity regarding new endeavors (see Bourdieu, 2000, p. 104ff). Therefore, project implementation cannot but build on village-internal disparities. It will principally favor those able to invest into an entirely new endeavor, displaying certain standards in terms of hygiene and cultural openness, who are rarely to poorest of the poor. Disparities between rather well-off and poor households are thus likely to be reproduced or even exacerbated by the creation of an intracommunal gap between households who directly benefit from tourism and those who do not.

Furthermore, traditional gender roles, in which women carry the bulk of a household's workload, are reinforced (although women are generally the main beneficiaries of such projects in monetary terms): tourism responsibilities add to the daily tasks and affirm the traditional division between men and women in terms of hospitality. Domestic tasks like cooking, preparing the lodge, serving or handicraft are women's work while communing with guests, guiding etc. is a predominantly male task. Women are crucially underrepresented also among the provincial and national guides. Beyond such structures of intracommunal disparity, ecotourism necessarily creates intercommunal ones: a classical ecotour, for example, consists of an entrance village, an overnight village and a village of departure back into town. Among these villages the overnight village will naturally benefit most since most services are provided here. This 
regularly leads to tensions within particular projects and which may intermingle with more "traditional" suspicions among neighboring communities (e.g. in terms of religion or ethnicity). Also between two villages which serve as overnight villages alternately similar tensions arise. Ecotourism becomes an object of communal and intercommunal rivalries. Although it may contribute substantially to local funds, it was so far not able in Laos to replace subsistence activities regarded as unsustainable, such as slash-and-burn cultivation or hunting. This is unsurprising given the contradictory demand that "hosts" should remain real peasants and that tourism development should be limited. This preset of restricted development seems inadequate in the light of local and national development aspirations (also Butcher, 2007).

\section{Lao NPAs in an extractive landscape}

NPAs are not only to be seen as "factories" of resources to be capitalized in the future, but they are also immediately productive. Protected areas in Laos are generally situated at a "relational resource frontier" where several resource uses intersect and overlap, enclosing land for private accumulation (Barney, 2009). Put differently, conservation in Laos is part of a generally extractive landscape and plays its constitutive part in socioecological transition, divorcing labor from land (e.g. Kelly, 2011).

The productive link between conservation and large-scale resource extraction is most clear, although rarely mentioned, in the NPA-hydro dam nexus. Thanks to its geographic situation, a main- stay of Lao development is to turn the country into the "Battery of Asia" mainly via the extraction of electricity from the power of the Mekong and its tributaries. The exploitation of this comparative advantage necessitates healthy watersheds, more or less intact forests above hydroelectric dams. This essential "environmental service" is recognized by the Lao government, which pioneers hydropower levies (ICEM, 2003; Mainusch et al., 2009). The Nam Theun 2 project, one of the biggest hydropower projects in the region, provides USD 1 million for the Watershed Management Conservation Agency (WMPA) of Nakai-Nam Theun NPA (a major nature reserve in the region), which safeguards the "protection, conservation and management of the Nakai Nam Theun 2 watershed and its rich biodiversity and forest to supply enough water with low sedimentation to the NTPC multipurpose project $[\ldots]$ ", according to the agency's Social and Environment Management Framework and Operational Plan (SEMFOP). Thus, people are not only subjected to NPA regulations and management but ultimately to the healthy watershed premise of large-scale hydropower, which, on the other end of the production line, downstream, has adverse social and ecological effects ${ }^{13}$. Moreover, such large projects are oriented towards abstract figures such as the GDP, which often stands in contradiction with local wellbeing14. Dam levies are transfer payments that should not impede on profitability; the NT2 levy "represents less than half of one percent of gross revenues" (ICEM, 2003, p. 69). This nexus of productivity also exists where no levies are paid.

\footnotetext{
13 Nam Theun 2, for example, was widely criticized for its various negative impacts, from problems with resettlement and logging prior to inundation up to current downstream health issues, increasing $\mathrm{CO}_{2}$ emission, and increased pressure on the NPA because of easier access (e.g. McDowell et al., 2014).

14 This goes along with Marx observation of "the identity between the wealth of the nation and the poverty of the people" (Marx, 1982, 886).
} 
Conservation is systemically integrated in Laos' extractive landscape also in more twisted ways. Not just dams, but also illegal timber and wildlife trade stand in a productive tension with conservation. While these modes of extraction directly undermine conservation legislation and goals, they are also a function of it: NPAs are primary source areas for illegal trade (Nooren \& Claridge, 2001, p. 214). Trade in endangered species is spawned by modernization and increasing rural-urban divide. Forest products are in great demand by a thriving urban upper-middle class (first of all in China) seeking distinction through conspicuous consumption of rare, expensive and wild things. Trade focuses on protected areas because the concentration of valuable (endangered, prohibited, rare) species is normally highest there ${ }^{15}$. Generally, prices for wildlife rise with protection since transaction costs increase, which, in turn, increases incentives for extraction as well as the distinction value of a certain product. Adding to this are internal dynamics of resource isolation within PAs: adjacent people are, by integration into ICDPs (section 3), subjected to a logic of restricted development that keeps them near the poverty line while poverty could be done away with here and now, and isolated legally from the resources for subsistence. An impoverished population thus lives alongside high-value resources, rendering poaching even more likely. Given huge profit margins, local people are often part of such networks as cheap extractors who derive temporary wealth from the sell-out of irreplaceable species.

\section{Conclusion}

This article dealt with the nexus of conservation, productivity and inequality on the basis of research in Laos. It argued that conservation is essentially entangled with productivity as well as with social inequities. Through NPA designation, the product of local labor is appropriated and access legally restricted while local subsistence continues to depend on the immediate environment. Such exclusion is softened by inclusive practices like ecotourism which, as argued, ultimately exclude locals in that the social positions of and inequities between "hosts" and "guests" are cemented and affirmed. Thus, instead of resulting in outright violence against local populations, the social exclusiveness of conservation is veiled and enacted in inclusive practices. The turning of subsistence peasants into ecosystem servants via ecotourism is ecological instrumentality at work in that locals are handled according to supra-local interests in creating resource reservoirs for future private accumulation.

Not only are NPAs designated in impoverished marginal places where their restrictions tend to run counter to local needs and aspirations; inclusive approaches turn people into legitimate servants of a cause not their own while keeping them poor and marginal. The role of "biodiversity steward and custodian" is ready-made elsewhere based on fictions alien to and imposed on local realities (such as "pristine nature"). Locals are legally kept out of an environment they continue to depend on, while these conserved patches of land become subject to

15 Protection itself sometimes fuels demand, but this is not always the case: the Saola ("Asian unicorn"), although an exceptionally rare and endangered species, did not find much commercial interest on part of Chinese medicine (Robichaud, pers. comm.). It is threatened with extinction nevertheless because animals are killed as by-catch; see: http://www.tomdispatch.com/post/175968/tomgram:_william_debuys,_a_global_war_on_nature/\#more, accessed March 2015. 
illicit extraction that serves to enrich those in power. Because a role as ecosystem servant does not reflect local realities and aspirations and hardly satisfies local needs, such imposition tends to become undermined almost necessarily: unsurprisingly, those locals with links to powerful patrons or merchants likely tap into networks of illicit extraction in order to compensate for the exclusion effected through conservation. Thus, the global increase in protected areas is not in principle better if inclusive. Domination in inclusive approaches works by keeping the conflict between "nature" and "society" latent. Thus, regardless of whether inclusive or exclusive: the extension of PAs worldwide signals the spread of domination via the false alternative of ecological instrumentality.

\section{References}

Adams, W.; Hutton, J. People, Parks and Poverty: Political Ecology and Biodiversity Conservation. Conservation and Society, 5(2), 147-183, 2007.

Baird, I. G. Turning Land into Capital, Turning People into Labour: Primitive Accumulation and the Arrival of Large-Scale Economic Land Concessions in the Lao People's Democratic Republic. New Proposals: Journal of Marxism and Interdisciplinary Inquiry, 5(1), 10-26, 2011.

Baird, I. G.; Shoemaker, B. Aiding or Abetting? Internal Resettlement and International Aid Agencies in the Lao PDR. Toronto: Probe International, 2005.

Barney, K. Laos and the Making of a "Relational" Resource Frontier. The Geographical Journal, 175(2), 146-159, 2009.

Bertzky, B.; Corrigan, C.; Kemsey, J.; Kenney, S.; Ravilious, C.; Besançon. C.; Burgess, N. Protected Planet Report 2012: Tracking Progress Towards Global Targets for Protected Areas. Gland: IUCN, Cambridge: UNEP-WCMC, 2012. Available at: $<$ http://cmsdata.iucn.org/downloads/ protected_planet_report.pdf>. Access in: Apr. 2014.

Bourdieu, P. Die zwei Gesichter der Arbeit. Interdependenzen von Zeit- und Wirtschaftsstrukturen am Beispiel einer Ethnologie der algerischen Übergangsgesellschaft. Konstanz: UVK, 2000.

Butcher, J. Ecotourism, NGOs and Development: A Critical Analysis. London/N.Y.: Routledge, 2007.

Demirovic, A. Nomos und Habitus. Anmerkungen zu Gesellschaftstheorie, Arbeitsteilung und Herrschaft bei Adorno und Bourdieu. In: Bauer, U.; Bittlingmayer, U.H.; Keller, K.; Schultheis, F. (Eds.). Bourdieu und die Frank- furter Schule: Kritische Gesellschaftstheorie im Zeitalter des Neoliberalismus. Bielefeld: Transcript, 251-263, 2014.

Dowie, M. Conservation Refugees: When Protecting Nature Means Kicking People Out. Orion Magazine November/ December 2005, 2005. Accessible at: <http://www.orionmagazine.org/index.php/articles/article/161/>. Access in: Apr. 2015.

Duffy, R. A Trip Too Far: Ecotourism, Politics, and Exploitation. London: Earthscan, 2002.

Global Environment Facility (GEF). Lao People's Democratic Republic Environmental Assessment Report: Developing and Demonstrating Replicable Protected Area Management Models. Vientiane: Global Environment Facility Medium-Size Project, 2012.

Görg, C. Regulation der Naturverhältnisse. Zu einer kritischen Theorie der ökologischen Krise. Münster: Westfälisches Dampfboot, 2003.

Lao People's Democratic Republic. Forest Law, Vientiane: National Assembly, 2007.

Gunn, G. C. Rebellion in Laos: Peasant and Politics in a Colonial Backwater. Bangkok: White Lotus, 2003.

Horkheimer, M.; Adorno, T. W. Dialectic of Enlightenment: Philosophical Fragments. Stanford: Stanford University Press, 2002.

Igoe, J. The Spectacle of Nature in the Global Economy of Appearances: Anthropological Engagements With the Spectacular Mediations of Transnational Conservation. Critique of Anthropology, 30(4), 375-397, 2010. 
International Centre for Environmental Management (ICEM). Lao People's Democratic Republic National Report on Protected Areas and Development. Indooroopilly, Queensland, 2003.

Kelly, A. B. Conservation Practice as Primitive Accumulation. Journal of Peasant Studies, 38(4), 683-701, 2011.

Lyttleton, C.; Allcock, A. 'Tourism as a Tool for Development.' UNESCO-Lao National Tourism Authority Nam Ha Ecotourism Project External Review, 2002. Available at: <http://www.ecotourismlaos.com/directory/publications/nam_ha_ecotourism_project_phase_i_external_review_2002.pdf $>$. Access in: Apr. 2015.

MacKinnon, J.; MacKinnon K. Review of the Protected Area System in the Indo-Malaysian Realm. Gland: IUCN, 1986.

Mainusch, J.; Tauszig, J.; Dongjun Y. Visian: Watershed Management in Lao PDR: A Case Study of the Opportunities for Hydropower and Forestry, Group 5. Group work report for the course "Forest Landscape Restoration in the Mekong River Basin", Vientiane: National University of Laos, 2009.

Marx, K. Capital: A Critique of Political Economy, Volume 1. Harmondsworth et al. Penguin Books, 1982.

McDowell, D.; Scudder, T.; Talbot, L. M. Nam Theun 2 Multipurpose Project: Twenty Second Report of the International Environmental and Social Panel of Experts, 2014. Available at: <http://www-wds.worldbank.org/external/ default/wdscontentserver/wdsp/ib/2014/06/03/000470435 20140603082231/rendered/pdf/883560wp0p07640e0rep ort00220and0lom.pdf>. Access in: Apr. 2015.

McElwee, P. Lost Worlds and Local People: Protected Areas Development in Vietnam. In: Chatty, D.; Colchester, M. (Eds.). Conservation and Mobile Indigenous Peoples: Displacement, Forced Settlement and Sustainable Development. New York, Oxford: Berghahn, 269-312, 2002.
Moore, J. W. Capitalism in the Web of Life: Ecology and the Accumulation of Capital. London/N.Y.: Verso, 2015.

Nooren, H.; Claridge, G. Wildlife Trade in Laos: The End of the Game. Amsterdam: The Netherlands Committee for IUCN, 2001.

Phimmavong, S.; Ozarska, B.; Midgley, S.; Keenan, R. Forest and Plantation Development in Laos: History, Development and Impact for Rural Communities. International Forestry Review, 11(4), 501-513, 2009.

Rehbein, B. Globalization, Culture and Society in Laos. London/N.Y.: Routledge, 2007.

Robichaud, W.; Marsh, C. M.; Southammakhot, S., Khounthikhoummane, S. Review of the National Protected Area System of Lao PDR. Vientiane: Lao-Swedish Forestry Programme, 2001.

Schmidt, A. The Concept of Nature in Marx. London: NLB, 1971.

Scott, J. C. The Moral Economy of the Peasant: Rebellion and Resistance in Southeast Asia. New Haven: Yale University Press, 1976.

Scott, J. C. The Art of Not Being Governed. New Haven, London: Yale University Press, 2009.

Singh, S. Natural Potency and Political Power: Forests and State Authority in Post-Socialist Laos. Honolulu: University of Hawai'i Press, 2012.

Stuart-Fox, M. Buddhist Kingdom, Marxist State: The Making of Modern Laos. Bangkok: White Lotus, 2002.

Turton, A. Introduction to Civility and Savagery. In: Turton, A. (Ed.). Civility and Savagery: Social Identity in Tai States. Richmond: Curzon Press, 2000. p. 3-30.

Vandergeest, P. Land to Some Tillers: Development-Induced Displacement in Laos. International Social Science Journal, 55(175), 47-56, 2003. 